DOI: $10.20472 / S S .2015 .4 .4 .002$

\title{
LABOUR MARKET DEVELOPMENTS IN VISEGRAD COUNTRIES
}

\section{ROMAN KLIMKO}

\begin{abstract}
:
On 1 May 2004, the Czech Republic, Hungary, Poland and Slovakia and another six states joined the European Union. From the early beginning it was an obvious fact that growth potential of all Visegrad countries is undeniable. However, the global economic crisis hit the labour markets of V4 countries significantly, but differently. The goal of the paper is to identify $\mathrm{V} 4$ labour market developments and to examine the impact of the economic development on them. The emphasis is being placed on the development of the selected specific unemployment issues - youth and long-term unemployment. The last section identifies great potential of green jobs and it concludes that training courses focused on green jobs coordinated with Public Employment Services may have strong positive effects on V4 labour markets.
\end{abstract}

\section{Keywords:}

Visegrad countries, labour market, unemployment issues, green jobs

JEL Classification: J01, $J 08$

\section{Authors:}

ROMAN KLIMKO, University of Economics in Bratislava, Slovak Republic, Email: romanklimko@gmail.com

\section{Citation:}

ROMAN KLIMKO (2015). Labour market developments in Visegrad countries. International Journal of Social Sciences, Vol. IV(4), pp. 16-29., 10.20472/SS.2015.4.4.002 


\section{Introduction}

In May 2014, the Visegrad countries (V4) ${ }^{1}$ were celebrating the tenth anniversary of EU Membership. Benefits of joining the EU were apparent at the very beginning and associated with four fundamental freedoms - free movement of goods, services, people and capital, including greater choice of products and inflow of foreign capital from EU states. The EU membership also extended opportunities to travel to the "old" Member States as well as to do a business, to work or study over there. However, EU membership meant increasing pressure to create a better business environment and at the same time new business opportunities for competitive firms have been created. The V4 countries also gained full access to structural funds, which was limited before joining EU. It definitely helped them to finance investments in regional development, to increase competitiveness and employment. The EU membership also brought the transfer of a number of important competencies in various areas, many times over-regulation, as well as the outflow of skilled labour force abroad and disappearance of certain businesses due to increased competitive pressure.

The second section of the paper deals with economic developments in V4 countries. The third section presents an overview of labour market developments in the Czech Republic, Slovak Republic, Hungary and Poland since EU accession in 2004. The major contribution of the forth section is to explore the employment opportunities for V4 countries in the field of green economy and employment. The importance of green economy and its potential of creating new jobs are obvious and it is constantly highlighted by the European Commission (2012b), OECD (2012) and the United Nations (UNEP 2008).

\section{Economic developments in V4}

The period after EU accession in 2004 could be divided into two periods, before and after crisis. The financial crisis has affected V4 economies in many ways, but it can be concluded that the common effects of the financial crisis were (Sobják 2013):

- a sharp decrease in GDP,

- decrease in exports because the demand in the EU was falling,

- an industrial production and the construction sector declined,

- the capital outflow from the V4 area.

The substantial fall in GDP led to significant increase in unemployment rates across V4 countries. The nature of $\mathrm{V} 4$ economies is that they are open, small (except Poland) and

\footnotetext{
${ }^{1}$ The Czech Republic, Hungary, Poland and Slovakia
} 
highly export-oriented, it means, their exposure to negative trends in global economy is quite high.

The economy of the Slovak Republic is one of the most dynamic in the European Union. It is a small and open economy that means exports make up a large part of GDP. However the greatest strength can also be the biggest weakness. In the period from 2004 to the onset of the crisis, GDP growth was among the highest in EU, also supported by strong productivity growth. The fall in GDP in the wake of the crisis was one of the highest (OECD 2013). The period after joining the European Union is characterized by acceleration in economic growth, and its dynamics has significant impact on the labour market in the direction of a decrease in unemployment and creating more permanent jobs. However, in Slovakia remained strong regional polarization of labour market, income inequalities within the state and the regions. In terms of Slovakia there was a sharp increase in GDP before the onset of the crisis. The GDP growth in 2007 peaked at more than $10 \%$. Comparing the other V4 countries it can be conclude that the fall of GDP growth in Slovakia was enormous, from $10.5 \%$ in 2007 to $-4.9 \%$ in 2009 . Luckily, as shown in the graph 1 , recovery was quite swift. The strong growth in the period before the crisis was driven by major export oriented FDI inflows, but mainly into the western regions of Slovakia (OECD 2014a). It means that benefits from high GDP growth are seen mostly in the western part of the state. It is necessary to add that exports of goods and services are ca 95\% of GDP. Nevertheless, growth is dependent mainly on the situation in automotive and electronic industries.

The Czech economy is a stable, small and open economy, closely integrated with the European Union. The country is considered as export economy with strong machinery and automotive industry, closely connected with Germany as its main export partner. Before the financial crisis that occurred in 2008, the Czech Republic experienced the longest period of uninterrupted growth ever (European Commission 2014a). The strategy was based on attracting FDI and positive labour market situation. When Germany slid into recession in November 2008, demand for Czech goods shrank dramatically and real GDP fell sharply in 2009 (graph 1). There was a slow recovery in 2010 and 2011. However, in the next year the Czech economy fell back into the recession. Comparing the other V4 countries, the Czech Republic was the only V4 country with negative GDP growth in 2013. The Czech economy has remained weak for longer time than the majority of EU countries. The recovery started in the second half of 2013. The reasons could be seen in a lack of external demand and because of austerity measures taken by the government (OECD 2014b).

The developments in the Hungarian economy are quite different. The serious slowdown of the economy could be seen since the beginning of the year 2006. Regarding GPD growth is obvious that the crisis has hit Hungary a bit earlier than the other V4 countries. In April 2006, the Hungarian government adopted a package of austerity measures in order to reduce the budget deficit. That was the reason of slowing down in next two years. Although 
the GDP growth fell below zero not until 2009, the years 2007 and 2008 could be called as stagnation, with GDP growth $0.1 \%$ and $0.9 \%$ respectively. Hungary was also forced to agree and take a loan from the IMF in October 2008. There was a sharp decrease in GDP growth in 2010 (graph 1). After another GDP decline (1.7\%), Hungary got out of recession in 2013, with GDP growth of $1.1 \%$. However, weak investment, low employability of lowskilled workers and shortcomings in labour and product markets held back growth potential. All in all, further structural reforms are essential (OECD 2014c).

\section{Graph 1: GDP growth in V4 countries and EU-28 between 2004 and 2013 (in \%)}

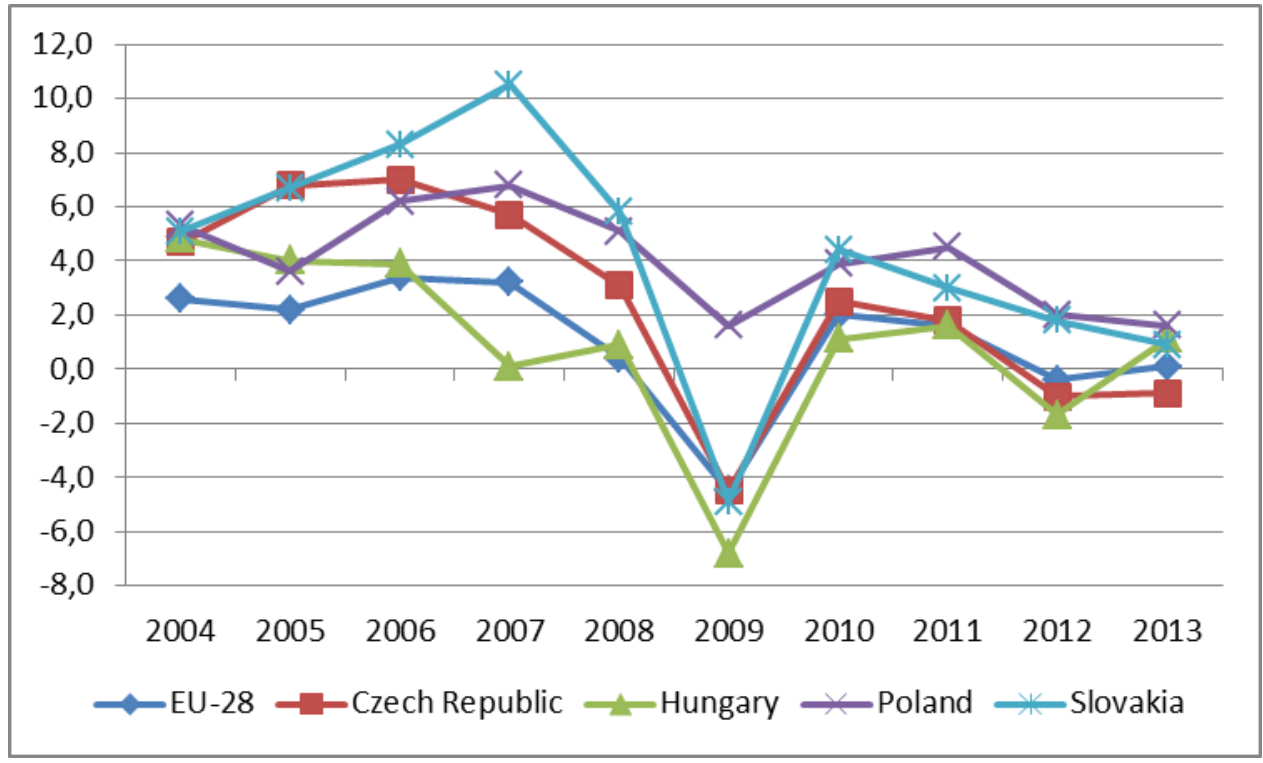

Source: Eurostat, own processing.

Note: GDP at market prices, percentage change over previous period.

Comparing all V4 countries, Poland is the only one that has not met the negative GDP growth since joining the EU. The economic performance has been impressive since EU accession in 2004. The success of Poland in tackling the crisis is quite impressive. There are couple of reasons for positive development in GDP growth and for answer the question: why was Poland's economy that resist to the global shocks? Firstly, at the beginning of the crisis in Europe, fiscal structure and banks were stable. Moreover, the Polish currency has not been pegged to the euro and it helped central bank of Poland. Depreciation of Polish

currency facilitated to increase competitiveness in case of exports. Another important thing is that the Polish economy is not that open as the other V4 countries. And finally, the size of the Polish economy, robust domestic demand and consumption helped to overcome deteriorating economic conditions since the onset of the financial crisis (Sobják 2013). Yet, a bit surprising was that the economy slowed down in 2012 and 2013. That means the important challenges remain. 


\section{Labour market developments in V4}

\section{Labour market situation}

After accession to the EU, the labour markets of V4 countries experienced significant changes. Any measures aimed at preventing significant labour migration were gradually removed. Free movement of persons as the main objective was clear. Developments in the labour markets after joining the EU can be divided into two periods (graph 2), however, differed significantly in nature (Šikulová a kol. 2014). The onset of the crisis in 2009 represents the dividing line and it left the significant negative phenomena in the V4 labour markets which are very difficult to overcome nowadays. Therefore, it is a crucial issue to cope with unemployment, because it represents the unused value of the economy and it is a social indicator associated with adverse social phenomena (Pongráczová, 2011). However, policy-makers in the V4 countries focus on certain policies that suit their needs in order to avoid implementing the politically sensitive recommendations (Szüdi Kováčová, 2014).

\section{Slovak Republic}

The labour market in Slovakia has been hard hit by the crisis. Total unemployment, youth unemployment and long-term unemployment are the major problems the Slovak Republic is facing. The most important problem the Slovak labour market needs to deal with is undoubtedly a long-term unemployment. While the number of unemployed has declined continuously since 2001, the number of long-term unemployed has increased its share of total unemployment. In 2013 , more than $70 \%$ of unemployed were unemployed more than 12 months, the highest share not only in V4, but also across the EU. In 2007, there was a problem with the reduction in unemployment rate and the cause was mainly a large number of long-term unemployed in the labour market, either without work habits, or not willing to move to work. The graph 3 shows that the situation in case of long-term unemployment remains more or less stable since 2004 (except year 2009) and we cannot see any positive improvements. While in 2004 the long-term unemployment was at the level of $64.7 \%$ of total unemployment, in 2013 it was $70.2 \%$ and this is extremely high. Also, it is necessary to emphasize high unemployment among young people under 25. Every third economically active in this age group is unemployed, what is the worst among V4 countries. Frustration of young people of job prospects can be a destabilizing factor in the development of longterm unemployment. The developments in unemployment rate of young people can be seen in graph 4. Of course, there were some positive improvements between 2007 and 2008, but later the situation has deteriorated and high levels of unemployment which could be seen before crisis came back. The Slovak government knows that current situation needs solution so that a couple of new instruments will be implemented in order to improve the performance of the labour market. The measures are related mainly to employment services to make them more efficient and effective for disadvantages job-seekers. Also, 
other measures are aimed at young people under 29, long-term unemployed and Roma communities (NRP 2014a).

\section{Graph 2: Unemployment rate in V4 countries and EU-28 between 2004 and 2013 (in \%)}

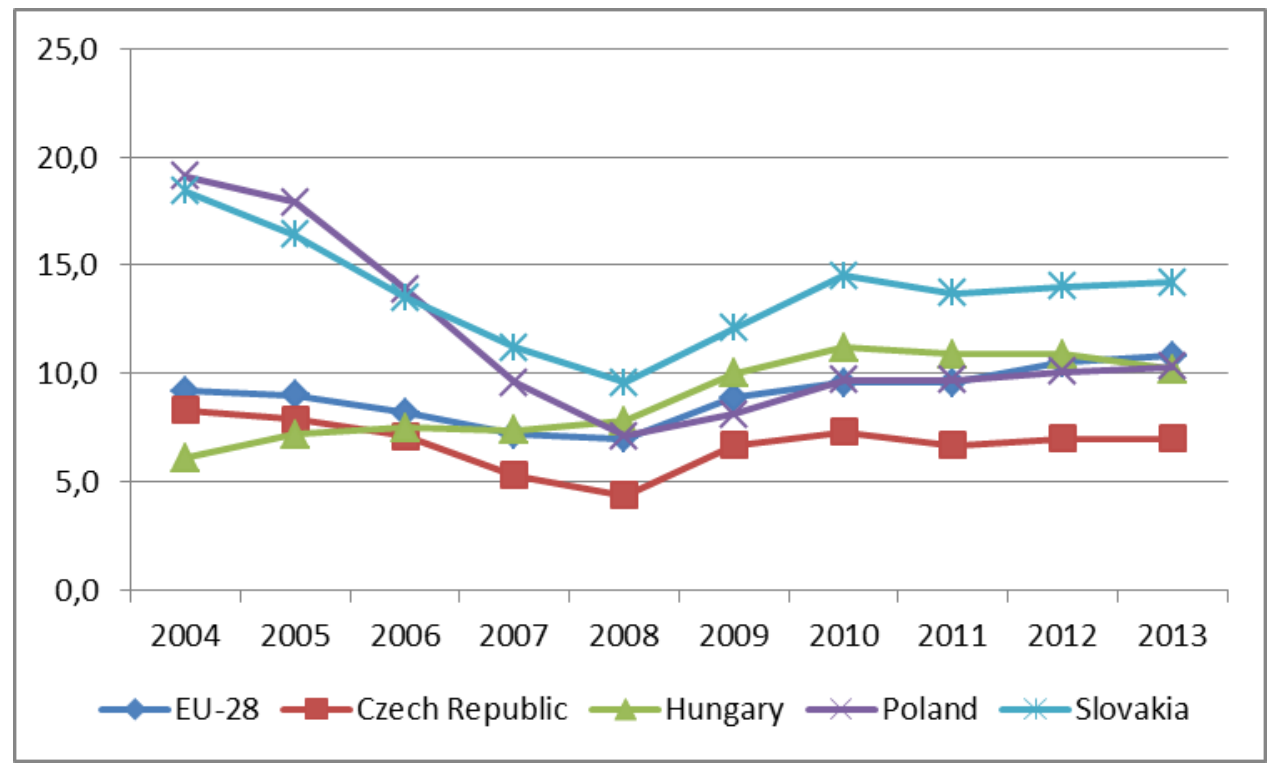

Source: Eurostat, own processing.

Czech Republic

Comparing the situation across V4 countries, the labour market indicators in the Czech Republic are quite good. The development of unemployment rate since joining the EU can be seen as a success. It started at the level of $8.3 \%$ in 2004 , than it lowered to $4.4 \%$ in 2008 and finally, it reached $7.0 \%$ in 2013 (graph 2). The level of $7.0 \%$ is the lowest unemployment rate among V4 countries and it is also 3.8 percentage points (pp) lower than EU average. However, the financial crisis revealed some structural problems; e. g. the labour demand has changed towards a more qualified labour force, without significant reaction of the government. Since 2008, the unemployment rate rose and affected mainly low-skilled and young people (OECD 2014b). The youth unemployment reached $19.5 \%$ in 2012 (graph 4), what is a big difference, if we compare it with total unemployment rate. The government has got a plan to deal with it, e. g.:

- better career guidance;

- improved information provision;

- facilitation of participation in active labour market policies;

- workplace training. 
Graph 3: Long-term unemployment in V4 countries and EU-28 between 2004 and 2013 (in \% of unemployment)

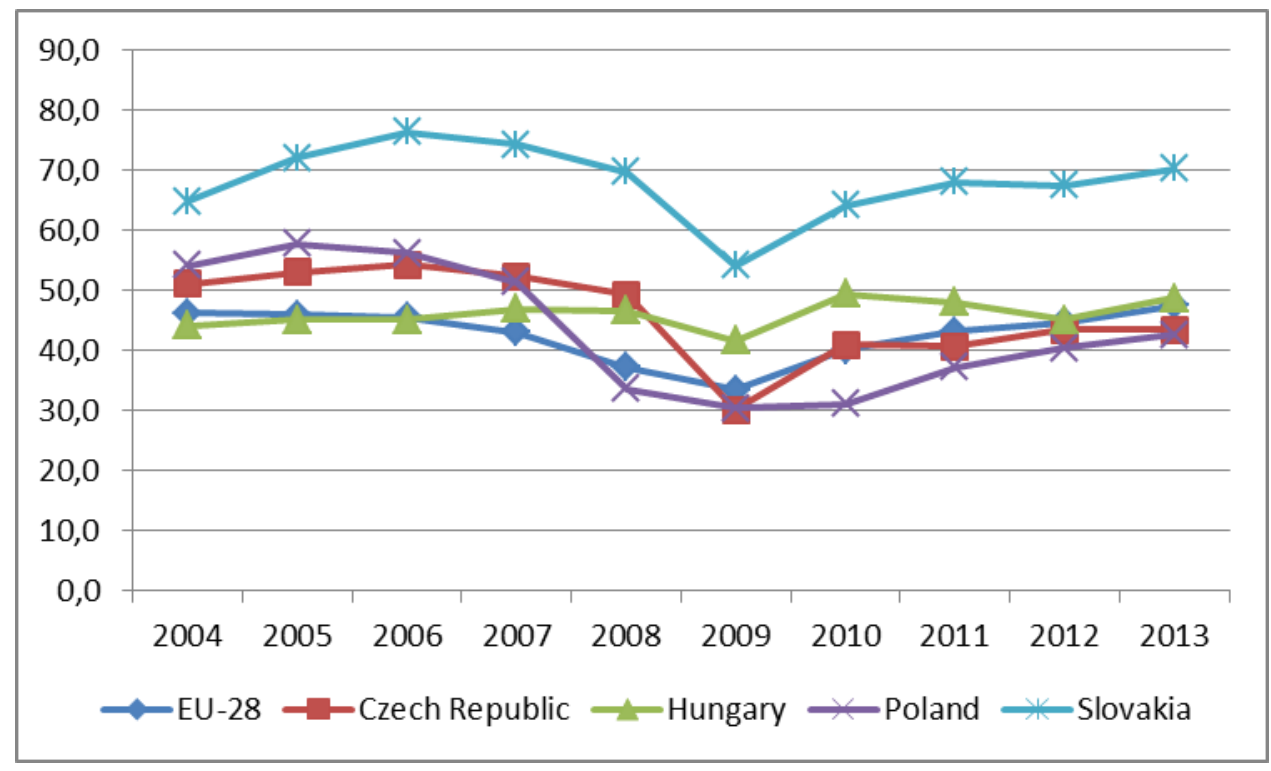

Source: Eurostat, own processing.

Another structural problem in the Czech labour market is the persistence of high long-term unemployment rate (graph 3 ). There is $43.4 \%$ of the unemployed without a job for longer than 12 months. Active labour market policies could help in that situation to raise the employability of low-skilled and young people who left education system and have no skills needed in the labour market. However, the spending on active labour market policies in the Czech Republic is low and not that well targeted. A Youth Guarantee Programme was adopted with its aim to offer employment, further education, training or internship to everybody under 25 . The offer needs to be within 4 months after becoming unemployed. The implementation of the programme is via existing 31 projects for youth (NRP 2014b).

\section{Hungary}

There are some visible improvements in labour market situation due to couple of reforms they had been made in the past years. However, Hungary still needs a lot to do in order to deal with challenges that country faces, namely structural problems and low economic growth.

Hungary adopted a couple of measures in order to mobilize labour force and boost employment in the past years, e. g. (European Commission 2014b):

- the reform of the social service system to promote work,

- a reinforcement of active labour market instruments,

- the launching of new Public Work Programme, 
- an adoption of new Labour Code,

- the transformation of labour income taxation,

- the reform of the tax system,

- an implementation of a new employer benefit system, which reduces employment costs directly,

- the reforms in the fields of vocational and adults training.

Despite the fact that the country has introduced a number of measures, the new ones need to be adopted. In 2004, unemployment rate was 6.1\% (graph 2). Over the decade, it increased and it is stabilised around 10\% nowadays, which means ca 4 pp more than in year of joining the EU. If we compare V4 countries we can find out that for example in Poland in 2004 unemployment rate was 19.1\% (exactly 13 pp more that in Hungary) and in 2013 unemployment rate in Poland was $10.3 \%$ (only $0.1 \%$ more that in Hungary), what is quite interesting for comparison. As we mentioned above, there are couple of issues to deal with. One of the important barriers is labour taxation, especially for people with low wages. The jobseekers in Hungary also need more time to find their job in comparison with the three months period of unemployment benefit. Of course they may be forced to join public work scheme, but they can be stuck inside that scheme for a longer time or just take the first job even if it does not fit their qualification.

The youth unemployment in Hungary rose significantly since joining the EU, from $15.5 \%$ to $28.1 \%$ in 2012 (graph 4). Then, in 2013 decreased to $27.2 \%$ but still remains high. Some measures has already been undertaken in this area, e. g. retargeting active labour market policy to young people and support schemes for young entrepreneurs, or wage subsidies (European Commission 2014b). The country considers youth unemployment as a top priority and challenge. Another very important priority is to tackle a problem of long-term unemployment (NRP 2014c). Although there is not a significant rise over the years, the share of long-term unemployed among unemployed people increased from $44.0 \%$ in 2004 to $48.6 \%$ in 2013 , the second highest level across V4 countries (graph 3 ). 
Graph 4: Unemployment rate of young people in V4 countries and EU-28 between 2004 and 2013 (less than 25 years, in \%)

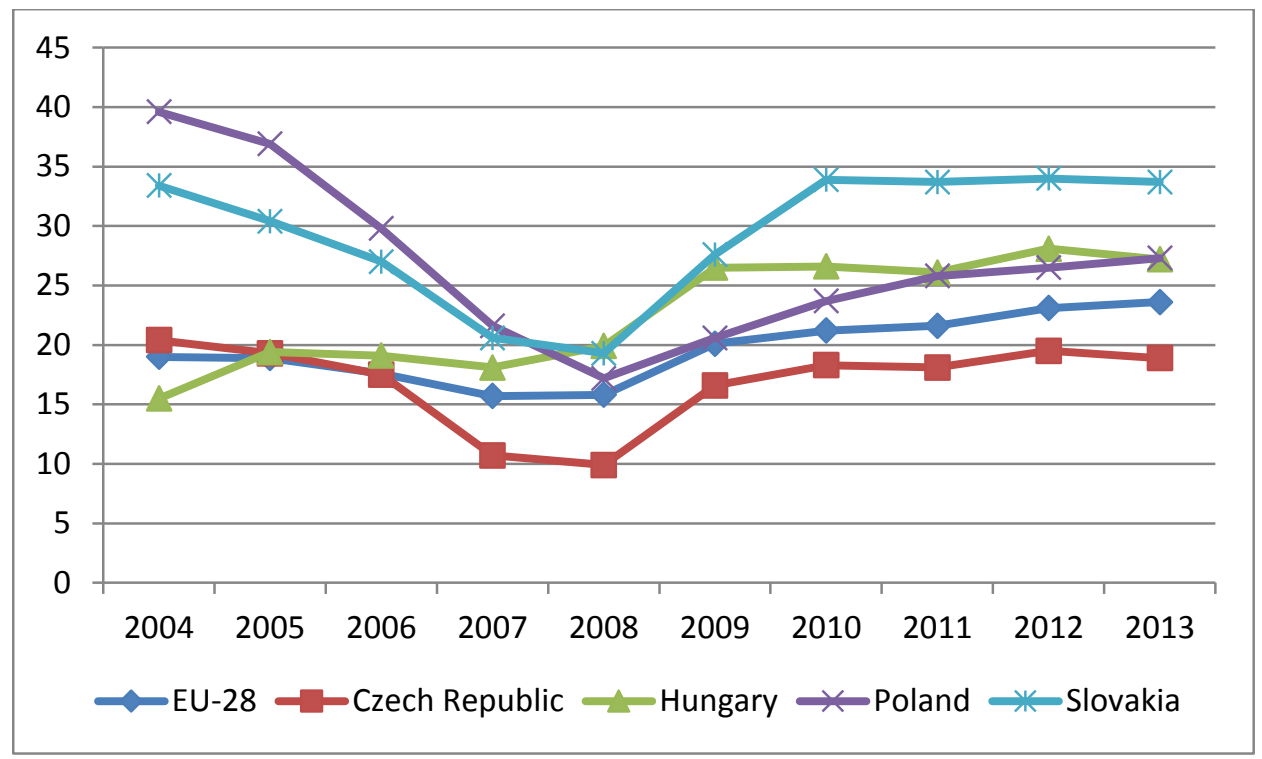

Source: Eurostat, own processing.

Poland

Labour market developments since Poland joined the EU are quite good at first sight. The level of unemployment rate decreased by $8.8 \mathrm{pp}$ since 2004 and it was $10.3 \%$ only compared with $19.1 \%$ in 2004 . So, what are the reasons? First of all it is mostly because of labour costs which are competitive, if we compare labour costs across the EU. It means that employees are not expensive for the companies, they are also productive, tax burden is not that high and labour law is flexible (European Commission 2014c). In order to make the labour market situation in Poland better, the government committed to undertake reforms in the field of labour market in National Reform Programme 2014/2015 (NRP 2014d). The government plans to introduce new labour market instruments mainly for vulnerable group in the labour market - young people under 30 and older people aged $50+$. Another issue is what to do with the consequences of the financial crisis if we speak about long-term unemployment. The Polish government stated that emphasis is being placed on measures which can maintain employment even in the case of decrease in economic activity, e. g. they plan to co-finance the training costs of employees who face economic downturn or who's working time is reduced. Also, the measure which will support employment through providing financial supplements to employees who are in the risk of dismissal in case of temporarily deteriorated business conditions.

Especially the high incidence of unemployment among young people is a burden. In 2013 the unemployment rate of young people peaked at $27.3 \%$, what is high level, taking into account $17.2 \%$ in 2008 (graph 4). Comparing the situation in 2004, when it was $39.6 \%$, it 
seems to be quite good nowadays. However, it is not. The rate is the second highest among V4 countries and the situation requires taking measures which would help the young people to find first job. Also, the problem is that there is a lack of access to quality apprenticeship and work-based learning. Some reforms have already been done in the field of vocational education and training system. The progress is obvious and it is going in the right direction (European Commission 2014c). As mentioned above, government has got a plan what to do and how to fight long-term unemployment. If we take a look at graph 3, we can see that Poland has the lowest level of long-term unemployed of total unemployed. In 2013 it was $42.5 \%$. It means that since joining the EU it has decreased by ca $11.5 \mathrm{pp}$ and this we can consider for success comparing with other V4 countries.

\section{Where will new jobs come from?}

In order to respond to the continuing high unemployment and low employment rate in the EU, in April 2012 the Commission introduced a set of measures with a clear objective, namely to promote job creation, entitled Employment Package. The Employment Package is a set of documents outlining the options to link employment policy at the EU level with a number of other policies to promote smart, sustainable and inclusive growth. It identifies potential areas of job creation and the most effective ways to create them within the EU. The Commission proposed measures in the following areas (European Commission 2012a):

a) Support job creation;

b) Restore the dynamics of labour markets;

c) Enhance the EU governance.

In the area of promoting job creation, the measures can be divided into three sub-areas (table 1): (a) stepping up job creation in all sectors of the economy fostering labour demand, (b) exploiting the employment potential of key sectors, and (c) mobilisation EU funds for job creation (for more see Klimko - Rievajová 2014). However, in the next section, attention will be paid to highlight green jobs as one of the key sectors with employment potential. 
Table 1: Measures to support job creation

\begin{tabular}{|c|c|}
\hline Section & Measures \\
\hline $\begin{array}{l}\text { Stepping up job creation in } \\
\text { all sectors of the economy } \\
\text { by supporting labour } \\
\text { demand }\end{array}$ & $\begin{array}{l}\text { - } \text { Targeting hiring subsidies to new hiring } \\
\text { - } \text { Reducing the tax wedge on labour in a budgetary } \\
\text { neutral way } \\
\text { - Supporting self-employment, social enterprises } \\
\text { and business start-ups } \\
\text { - Transformation of informal and undeclared work } \\
\text { into regular employment } \\
\text { - Boosting 'take home' pay } \\
\text { - Aligning wages and productivity }\end{array}$ \\
\hline $\begin{array}{l}\text { Exploiting the employment } \\
\text { potential of key sectors }\end{array}$ & $\begin{array}{l}\text { Job growth in sectors: } \\
\text { - Green economy } \\
\text { - Health and social care } \\
\text { - ICT }\end{array}$ \\
\hline $\begin{array}{l}\text { Mobilisation of EU funds for } \\
\text { job creation }\end{array}$ & $\begin{array}{l}\text { Using funds: } \\
\text { The European Social Fund (ESF) } \\
\text { The European Regional Development Fund (ERDF) } \\
\text { The European Progress Microfinance Facility } \\
\text { The European Globalisation Adjustment Fund (EGF) } \\
\text { The European Agricultural Fund for Rural Development } \\
\text { (EAFRD) }\end{array}$ \\
\hline
\end{tabular}

\subsection{Green jobs}

There are some growing sectors in the EU, e.g. digital economy, health care and green jobs. Sure, those sectors need a skilled workforce and it is education, which plays a key role in matching process. Moreover, the Europe 2020 is based on the assumption that green, low-carbon and energy efficient economy is crucial to achieve smart and inclusive 
growth. Inefficient use of resources, unsustainable pressure on the environment and climate changes, as well as social exclusion and inequality pose challenges for long-term economic growth. Green growth is a challenge and an opportunity for the labour market and skills that are key factors for enabling green growth. The transition will bring major changes in the overall economy and in a wide range of sectors, and thus create new jobs (OECD, 2012). In this context, it is important for better targeting and coordination of labour market measures and tools to establish the conditions necessary to promote green jobs, a support to overcome the mismatch between skills shortages and labour shortages, and anticipating changes in the needs of human capital. So, what the green jobs are? Green jobs include jobs that are dependent on the environment, or are created, substituted or redefined (in terms of skills, working methods, etc.) in the process of transition towards a greener economy. For example, more jobs will be created through the renovation of buildings, the development and introduction of new technologies such as renewables. Some employment in traditional cars production will be gradually replaced by production of hybrid cars. European Commission estimates that energy efficiency measures could create or maintain up to 2 million jobs and additional 3 million jobs could be created through the development of renewable energy sources by 2020 (European Commission, 2012b). There are two different sectors challenging the green jobs agenda, eco-industries (e.g. waste management, renewable energy...) and traditional industries (greening). Greening of jobs in traditional industries will not only continue in the future, but acceleration is predicted. In these terms, adaptation of the labour force is crucial, with retraining and displacement challenges. There is one great example from Belgium - The energy scanners project. This project includes training the long-term unemployed with low skills in the activities related to energy saving. Unemployed become energy scanners and they offer households free installation of energy saving devices. In addition, energy scanners provide professional advice on how to save energy. Services provided under this project were gradually extended into the services in the areas of recycling and insulation works like roof, walls and floors. Training courses are coordinated with Public Employment Services and provided by more than 30 social economy organizations. In 2011, there were about 34,000 households in Belgium benefited from the services of expert advice how to save energy. Moreover, these advices enabled them to cut their energy bills and/or use the offer of insulation. Through this project, about 4,000 people have found new jobs. Providing such a type of projects across the EU could help not only long-term unemployed, but also youth to get a great job and finally find a solution for high youth and long-term unemployment on the one hand. On the other hand, this kind of project is meaningful and sustainable.

\section{Conclusion}

Ten years after joining the EU we can conclude that it was the right decision for V4 countries. Although the positive developments since 2004 were hit hard by the crisis, the situation is much better than at the beginning in 2004. Nowadays, the V4 countries are economically stronger and if work together they have also stronger voice in the EU. In 
terms of labour market, the biggest issues that need to solve are: a) high youth unemployment rates; and b) long-term unemployment and to find out how to get long-term unemployed back to/to work. But one thing is quite interesting. Despite high unemployment rates across the EU, there are more than two million job vacancies. Sometimes the only issue is geographic mobility. People are not willing to move to another city/country because of social relationships. Among other employment issues, the most acute are long-term and youth unemployment and we need to pay serious attention to solving them. Because the longer you are unemployed, the harder it is to get hired and the more support is needed. Although V4 countries have some targeted active labour market programmes for long-term and youth unemployed, Public Employment Services tend to use most of the resources for more employable jobless people because this leads to better results in finding jobs for unemployed. As it is mentioned in the section Green jobs, there is no doubt that green economy is a growing sector with great potential. It seems that green jobs will spring up across all sectors and their growth potential seems to be sustainable. How it could work in each V4 country and Member State is shown above - The energy scanners project. Training courses coordinated with Public Employment Services may help long-term and youth unemployed to get hired through tailor-made training course on the one hand. On the other hand the growing green industry would get a skilled staff.

The paper is the outcome of project IGP I-15-106-00 "Možnosti zvyšovania zamestnanosti prostredníctvom vybraných odvetví".

\section{References}

EUROPEAN COMMISSION (2012a). Employment Package. Available at: http://ec.europa.eu/social/ main.jsp?catld=1039 \&langld=en.

EUROPEAN COMMISSION (2012b). Exploiting the employment potential of green growth. Available at: http://ec.europa.eu/social/main.jsp?catld=89\&langld=en\&newsld=1270\&moreDocuments=yes\&table Name $=$ news.

EUROPEAN COMMISSION (2014a). Assessment of the 2014 national reform programme and convergence programme for Czech Republic. Available at: http://ec.europa.eu/ europe2020/making-it-happen/country-specific-recommendations/index_en.htm.

EUROPEAN COMMISSION (2014b). Assessment of the 2014 national reform programme and convergence programme for Hungary. Available at: http://ec.europa.eu/europe2020/making-ithappen/country-specific-recommendations/index_en.htm.

EUROPEAN COMMISSION (2014c). Assessment of the 2014 national reform programme and convergence programme for Poland. Available at: http://ec.europa.eu/europe2020/making-ithappen/country-specific-recommendations/index_en.htm.

KLIMKO R. - RIEVAJOVÁ E. (2014). Consequences of economic processes on the labour markets of the EU and coordinated approach to tackling, [in:] Economic policy in European Union member countries.: conference proceedings XII. international scientific conference. Karviná: Obchodně podnikatelská fakulta v Karviné SU v Opavě, 2014, ISBN 978-80-7510-045-0. 
NATIONAL REFORM PROGRAMME OF THE SLOVAK REPUBLIC 2014 (NRP) (2014a). Available at: http://ec.europa.eu/europe2020/making-it-happen/country-specific-recommendations/index_en.htm.

NATIONAL REFORM PROGRAMME OF THE CZECH REPUBLIC 2014 (NRP) (2014b). Available at: http://ec.europa.eu/europe2020/making-it-happen/country-specific-recommendations/index_en.htm.

NATIONAL REFORM PROGRAMME 2014 OF HUNGARY (NRP) (2014c). Available at: http://ec.europa.eu/europe2020/making-it-happen/country-specific-recommendations/index_en.htm.

NATIONAL REFORM PROGRAMME OF THE REPUBLIC OF POLAND 2014 (NRP) (2014d). Available at: http://ec.europa.eu/europe2020/making-it-happen/country-specific-recommendations/index_en.htm.

OECD (2012). The jobs potential of a shift towards a low-carbon economy. Available at: http://www.oecd.org/employment/emp/50503551.pdf.

OECD (2013). Slovak Republic. Fostering an Inclusive Job-rich Recovery. OECD Publishing, Luxembourg.

OECD (2014a). OECD Economic Surveys: Slovak Republic. OECD Publishing, Luxembourg.

OECD (2014b). OECD Economic Surveys: Czech Republic. OECD Publishing, Luxembourg.

OECD (2014c). OECD Economic Surveys: Hungary. OECD Publishing, Luxembourg.

PONGRÁCZOVÁ E. (2011). Sociálna ekonomika. 1. vyd. Bratislava: EKONÓM, 2011.

SOBJÁK A. (2013). From the Periphery to the Core? Central Europe and the Economic Crisis. Policy Paper, PISM, No. 7 (55).

SZÜDI G. - KOVÁČOVÁ J. (2014). Väčšia flexibilita a viac pracovných miest? - Porovnanie aktuálnych zmien v regulácii trhu práce $v$ krajinách Vyšehradskej štvorky, [in:] Determinanty využívania flexibilizácie práce $v S R$ z pohladu rodiny a ich implementácia do sociálneho systému. Banská Bystrica: Ekonomická fakulta Univerzity Mateja Bela v Banskej Bystrici, 2014, ISBN 978-80-5570696-2.

ŠIKULOVÁ I. a kol. (2014). Slovenská ekonomika: desat' rokov Členstva v Európskej únii. Vybrané témy a problémy. EÚ SAV, Bratislava.

UNEP 2008. Green Jobs: Towards decent work in a sustainable, low-carbon world. United Nations Office, Nairobi. 